\title{
Existentialism as Reflected in Sting's Song Lyrics
}

\author{
Li Jia ${ }^{1, *}$, Li Yanfeng ${ }^{2}$, Meng Yue ${ }^{3}$, Quan Huiqi ${ }^{4}$ \\ ${ }^{1}$ College of Music, Shanxi Normal University, Taiyuan, Shanxi, China \\ ${ }^{2}$ School of Music, Shanxi University, Taiyuan, Shanxi China \\ ${ }^{3}$ Wenzhou University, Wenzhou, Zhejiang, China \\ ${ }^{4}$ Inner Mongolia Arts University, Hohhot, Inner Mongolia, China \\ *Corresponding author: lijia@sxnu.edu.cn
}

\begin{abstract}
Keywords: Absurdity, Alienation, Authenticity, Dread, Existentialism, Freedom, Lyric, Song, Sting.
\end{abstract}

Abstract: Sting is an international artist, and much of his music has been a reflection of his personality and his very vocal views regarding his advocacies in life. He writes about anything from love, relationships, death, politics, religion, etc. He is able to write songs that sound more like poetry than a typical pop song composition. As a clearly subjective being, he feels more than he thinks, so the emotion that is involved in his song writing is a clear manifestation of his existentialist tendencies. The study aims to validate the theories of existentialism as these are fleshed out from the lyrics of Sting in a limited selection of his songs. It seeks to provide an analysis of his songs set against that of an existentialist philosophical framework which consists of principle concepts such as: individual existence, subjectivity, choice and commitment, absurdity, and alienation. The study is both qualitative and quantitative in design and uses documentary analysis to bear out its premises and validate the impact of Sting's existentialist philosophy in his music. The existential characteristics used in the lyrics of the songs by Stings are Freedom and Responsibility, Absurdity, Dread, Alienation and Authenticity. These Existential characteristics were reflected in the lyrics of (30) thirty songs of Sting. Among the five characteristics of Existentialism mentioned, Dread or Anxiety is the most frequently used and reflected in the lyrics of the songs by Sting.

\section{Introduction}

The researcher's aimed to find out the use of the characteristics of existentialism in the songs of Sting. Existentialism's basic concern is man's existence, about his uniqueness compared with other beings (Waters, 1950; Pacifici, 1955). For the existentialist, man is more than what he is, he chooses what he'll be and how he'll relate to the world; it speaks of his freedom to be in a world that he has no full control of (Flynn, 2012). The human situation is best analyzed in terms of answering existential questions. Whenever man has looked at his world, he has found himself in it as a part of it (Mooney, 2018). And he also realized that he is a stranger in the world of objects, unable to penetrate it beyond a certain level of analysis (Skottun, et al., 2021). And then he has become aware of the fact that he himself is the door to the deeper levels of reality, that in his own existence he has only possible approach to existence itself. Whoever has penetrated into the nature of his own 
finitude can find the races of finitude in everything that exists. And he can ask the question implied in his finitude as the question implied in finitude universally, In doing so , he does not formulate a doctrine of man, he expresses a doctrine existence as experiences in him as man.

The analysis of human situation employs materials made available by man's creative self-interpretation, in all realms of culture. In the wake of scientific and industrial advances in the nineteenth century and the unprecedented destruction of two world wars in the twentieth, existentialist literature emerges as both a crisis of meaning and an ambivalent sense of possibility. The views to human life taken by existentialists readily connect with creative forms of expression, especially those of literary modernism. Existentialist thinkers such as Sartre, Beauvoir, and Camus' literary works, as well as modernist authors such as Rainer Maria Rilke, Kafka, Richard Wright, and Ralph Ellison, broaden the scope of existentialist philosophy. Among the numerous topics addressed in existentialist literature are absurdity, death, freedom, alienation, and the oppressive strain on human awareness (Gosetti-Ferencei, 2021).

The scope of existentialist literature has been changed such that it no longer functions as a fall into the dismal depths of one's unique mind. Rather, it triggers a meta-communication forum that expresses the sheer hardship of existing in a body that stings' music learns language in a world where our linguistic resources are the only thing that connects us together. The prevailing view of existential literature is that it depicts the dismal fall of a single individual's consciousness. However, when seen through the lens of existentialism, existentialist literature may be viewed as communication actions that stimulate the ontological problems that people confront while negotiating their social experiences.

\section{Existentialism as Literary}

To what degree does existentialism manifest itself as a literary phenomenon rather than a mainly philosophical one? Or, to put it another way, what shape does existentialism assume when it is regarded as literature rather than philosophy? Such issues emerge as a pretty direct result of the fact that a number of major existentialist works (or works widely recognized as such) are, in reality, works of literature - Nausea by Jean-Paul Sartre (La Nausée, 1938) and Albert Camus's The Outsider (L'Étranger, 1939) being two excellent examples - while some of the key figures within or close to the existentialist tradition have been literary rather than philosophical - arguably this is true of Camus, and certainly of Beckett. Rather than simply provide an exploration of existentialism in literature, or a survey of those literary works that figure within existentialism, this essay will also examine the idea of existentialism as literature, sketching a picture of existentialism as it emerges in literary rather than solely philosophical terms. Although it is sometimes argued that existentialism stands in a special relationship to literature - that it is an especially "literary" mode of philosophizing” (Malpas, 2012).

\section{Sting the Song Writer}

Sting is very effective in writing lyrical songs. His background as an English school teacher, added the struggles in his life, molded him into the ideal, prolific songwriter that he is. His music centers on love, estrangement and loneliness and evolves from one genre to another. According to Sting "It is very hard to talk about music in words. Words are superfluous to the abstract power of music. We can fashion words into poetry to that they are understood the way music is understood but they only aspire to the condition where music already exists."(Berkley College of Music commencement address 1994) Despite being performed on very concrete instruments, music itself is an abstract art. In writing about music writers must try to capture at least a portion of not only the 
meanings of the notes and words but also the emotions evoked and the very essence of the art form (Gable, 2009).

Sting's songs were from his deep emotions and experiences in life, from his unhappy childhood, to his struggle to be a popular artists, the failure of his first marriage, the death of his parents, the 9/11 tragedy, war, and the deterioration of the environment. He writes freely about his experiences and that of other people that is why he is able make songs that tell believable stories about the vulnerability man, the life of pain, and the struggles that the individual deals with in life. Apart from the theme of anxiety, Sting's songs reflect other existential themes, characteristics such freedom and commitment, authenticity, absurdity, alienation, boredom, and topics that perplex man, such as faith and death. Sting is a believer of freedom and often speaks his mind on the importance of individual existence. He believes in the continuous quest of re-inventing the individual and is a selfproclaimed survivor of the vague world that he lives in. There is no philosophy that could better haul out the true meaning of Sting's lyrics other than Existentialism. The Subjective man can only be understood through the use of a philosophy that does not only explore the subjectivity in him but also measures his being by means of the authentic life that he lives.

\section{Theory of existentialism}

Existentialism is a philosophical theory that was prominent in Europe from the early to mid-twentieth century, focusing on issues of identity and authenticity. Jean-Paul Sartre, Albert Camus, Soren Kierkegaard, and Martin Heidegger are among the major existentialist thinkers, with Soren Kierkegaard and Friedrich Nietzsche regarded as the "Fathers." Kierkegaard and Nietzsche started reflecting on the existential dilemma that became the philosophical movement's focal point. While philosophers agree on common themes (such as Identity, Angst, and Authenticity), they disagree on precise definitions and strategies for achieving or dealing with these themes. As a result, existentialism has been defined in many ways (Sartre, 1987).

In the end, existentialism is about freedom, action, and creativity. The person must first recognize that their life is not controlled by outside forces such as society, religion, or family. It is controlled only by them; they are the only ones who have the ability to determine how they live and, as a result, who they are. While there are certain parts of ourselves that we cannot alter, such as heredity (for Sartre, this is the en soi), the real power in shaping our identity comes in how we interact with the world around us. And it is through this activity that we develop both our own identities as well as something to offer to the world. These realizations do not come easily, which is why most existential works are filled with dread and anguish. They do, however, bring with them a ray of optimism. I hope we have the ability to define ourselves. Many existentialist thinkers' works concentrate on various ways to attaining this genuine construction of identity. Some, such as Kierkegaard, advocate coping strategies. Others, like as Sartre, concentrate on moral reasoning and consequences. Others, such as Nietzsche, describe an evolutionary process that must be followed in order to attain genuine creation. All, however, revolve around the freedom of choice, the necessity to act on one's own will, and the consequent genuine construction of identity (Rochberg, 1988).

"If we were to search for a name to convey the breakaway mood of the 1890s but without imposing a fictitious unity of style on the age, we could do worse than revert to Hermann Bar's term 'modernism' and speak of a stylistically open-ended 'modernist music' extending (with some latitude) from 1890 to the beginnings of ouija," writes musicologist Carl Dahlhaus. Another description proposed by Daniel Albright is "a probing of the boundaries of aesthetic creation." He defines the concept by contrasting the following methods or styles: Expressionism and New Objectivity, Hyperrealism and Abstractionism, Neoclassicism and Neobarbarism, Futurism and Mythic Method. According to Albright, the Modernist movement ended with World War II, 
whereas Postmodernism began in 1951 with John Cage's Music of Changes. The period span from the 1890 s to the mid-twentieth century seems to be the most widely recognized. However, in general, contemporary music is considered to be best defined by Ezra Pound's iconic phrase: Make it New (Cage, 2011).

By establishing similarities between philosophy and music, Existentialism and Modern Music remarks on both. Existentialism explains patterns in musical evolution, demonstrates the direct relationship between composer life-views and their works, and inspires listeners to discover the why behind every musical choice. Modern music, on the other hand, demonstrates that existentialism's reflection on the human condition goes beyond general morals and identity into all aspects of life.

\section{Objective}

The study endeavored to find out the extent of the use of existentialism in the lyrics of the songs composed by Sting.

\section{Research Questions}

The analysis sought the following underlying questions:

1) What are the characteristics of Existentialism:

(a) Free will or freedom of choice and responsibility of actions;

(b) Absurdity of life;

(c) Dread and Anxiety;

(d) Alienation; and

(e) Authenticity?

2) How are the above characteristics of existentialism reflected in the lyrics of the songs by Sting?

3) Among these characteristics of existentialism which one is the most frequently used and reflected in the lyrics of the songs by Sting?

4) What literary devices were used by Sting in the lyrics of his songs?

5) How did the most frequently used and reflected characteristics of existentialism in the lyrics of the songs affect the life of Sting as a person and musician

\section{The Characteristics of Existentialism}

\subsection{Free Will or Freedom of Choice and Responsibility of Actions}

Freedom is a condition wherein there are enough normal choices open to every person to allow for change, and diversity, both in the successive experiences of individual persons. Man is free to make choices in the course of his life. He has the power to choose alternatives and is in full control of his life using his own judgment in its conduct. The free man has primarily the individual power to control himself and acts in accordance to his values, beliefs and conscience. Although freedom is a given, it does not entail that each person can do as he or she pleases. Being responsible requires a commitment to self-awareness, the need to accept one's individuality and the drive to achieve selffulfillment amidst all constraints. He is also expected to accomplish his role of being the ideal representation of humanity; therefore he should really be cautious with the value he chooses to create. Choice is an act that involves free will and knowledge that is why man is expected to bear the sole responsibility for the decision he makes and the ends he pursues. 


\subsection{Absurdity of life}

The "absurdity 'of human existence is the necessary result of man's attempts to live a life of meaning and purpose in an indifferent, uncaring and Godless universe. The human life is ultimately meaningless by the fact of death and the inability of the individual to make rational sense of his experience. Man gains victory by focusing on his freedom, his refusal to hope, and his knowledge of the absurdity of his situation. He continues to perform his duty no matter how insignificant his action is. Man's proper allegiance is to man and not to abstractions or 'absolutes'. Life is meaningless, yet refusing to grant a meaning to life does not necessarily lead to the conclusion that it is not worth living. Despite man's irrational desire for unity, for absolutes, for a definite order and meaning to the objective nature, no such meaning exists. Man will die, but he shouldn't allow that fact to inform or constrain all of his actions or decisions. He must be willing to live in spite of death, create meaning in spite of objective meaninglessness, and find value in spite of the tragic, even comic, absurdity of what goes on around him. Absurdity is born out of a confrontation between human need and the unreasonable silence of the world and humanity must live in a world that is forever hostile or indifferent towards them.

\subsection{Dread and Anxiety}

Dread or anxiety is a consequence of the meaninglessness of human existence or the emptiness of the universe. It is a universal condition of human existence and is further described as the general apprehension in human life. Dread may be a means of God to call man to a commitment of a moral and spiritual life. It can also come from the fact that being free individuals we are bound to make choices. The dual problems of constant choices and the responsibility for those choices can produce dread in men. Dread also occurs when an individual is confronted with the impossibility of finding meaning in a meaningless universe. He is often confronted by unpredictable events that occur without any rational justification. Given a situation wherein he has no control of may trigger in him the feeling of dread or anxiety. All of these cases are products of the recognition that man's existence and the events that happen around him are not pre-determined. Unexpected things happen and a crisis happens when things fall below man's expectations. The universe does not offer an answer to all questions or a solution to problems. Therefore the only way to deal with this ambiguity is to value the individual's choices and actions. The feeling of dread should be recognized and felt, but behind the immersion on the emotion the individual has to decide whether he will allow it to dominate him or otherwise.

\subsection{Alienation}

Existentialist deals extensively with the characteristic of alienation because existentialists believe that each individual human being is fundamentally alone. One's essential lack of communication with others makes the individual ultimately responsible for his decisions. Alienation is a refusal that is directed against any position or attitude that has become fixed and then imposed on others. It is the refusal to accept objective classification of people and events. The refusal is made in the name of a conception of freedom. If man is free, there are no pre-conceptions about his nature and performance is acceptable. Man builds his own commitments and responsibilities and need accept no substitute for his own choices. Insofar as when man becomes part of an establishment, he loses the sense of his role in life. He is committed to a form of homelessness and stands by a conviction that he will never achieve his goals. The ultimate faith of the philosopher now is the faith in himself. His belief in his enterprise is a belief in the significance of his own experience. Alienation can also be seen when the individual refuses to live an authentic life. He gets alienated once he 
refuses to embrace his individuality and decides to be just a face in the crowd. Much worst is when the individual denies his actuality and pursues life in bad faith. For the Christian Existentialists alienation is defined as the estrangement of the individual soul from God. Though man seems to be detached from the Absolute being, feeling the alienation can be followed by a process of conversion or transformation until such time that the alienation of self and the dividedness of the soul finally overcome.

\title{
7.5 Authenticity
}

Authentic existence means taking responsibility for all actions that one freely chooses. The total freedom that man faces often throws him into a state of existential anguish wherein he is burdened by the hardship of having to choose all the time.. Authentic existence dictates that man has to live according to his own beliefs, meaning he should find meaning into the acts that he does and not from what other people say. He should not live in regard to what the society dictates because this would mean a life lived in bad faith. Bad faith which means pretending that one is not free and responsible for his actions; where the individual thinks that he is a mere victim of circumstances and are not accountable for his deeds and choices.

\section{Characteristics of Existentialism as Reflected in the Lyrics of the Songs by Sting}

After a comprehensive examination of the lyrics of the songs by Sting, the summary of the study are now presented:

\subsection{Freedom and Responsibility}

\author{
"Island Of Souls" \\ And Billy would cry when he thought of the future \\ Then what they call an industrial accident \\ Crushed those it couldn't forgive \\ They brought Billy's father back home in an ambulance \\ A brass watch, a cheque, maybe three weeks to live \\ What else was there for a riveter's son? \\ A new ship to be built, new work to be done \\ That night he dreamed of the ship in the world \\ It would carry his father and he \\ To a place they could never be found \\ To a place far away from this town, \\ A Newcastle ship with no coals \\ They would sail to the island of souls \\ Mm-bay mm-bay-day mm-bay \\ Mm-bay mm-bay-day mm-bay
}

This song is about the first son of a riveter's son who dreams of a bright future for him and his father, he longs for a life away from slavery in the shipyard. Being born in the shipyard, would mean a life of slavery, the same life that his father has been struggling with. But Billy did not subject himself to this limitation and decides to break free from the bondage in order to pursue his own dreams. Being free to choose what one wants to be is a right and just like the character Billy, one should value one's power to change his destiny.

"Let your Souls Be Your Pilot"

Let your soul be your pilot

Let your soul guide you

He'll guide you well 


\section{When you're down and they're counting \\ When your secrets all found out \\ When your troubles take to mounting \\ When the map you have leads you to doubt \\ When there's no information \\ And the compass turns to nowhere that you know well}

This song speaks of the need to rely on oneself when in face of doubt and uncertainty. Man is both burdened and blessed by the great responsibility of free will and the power of choice. His future is determined, in a large part by the choices he makes. He may not always control circumstances around him, but he can choose his response to whatever arises. Reclaiming the power of choice, man finds the courage to live fully in the world. Man's life represents an exercise of the power of choice, and his destiny is determined in a large part by the choices he makes.

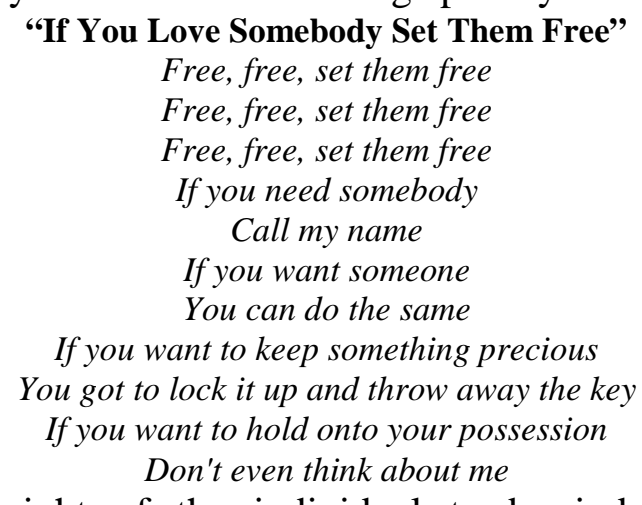

This song expresses the right of the individual to be independent and free. The song acknowledges the tendency of man to curtail another man's freedom for his own selfish motives, but it reiterated the need to treat man as a free-willed individual who cannot be objectified.The character in the song seeks for freedom. He feels that he is locked up and speaks of the reality that man cannot be chained nor be kept as a prisoner of somebody else. Man is a subject and never an object. Therefore, he cannot be possessed by another individual or the society.

"They Dance Alone"
One day we'll dance on their graves
One day we'll sing our freedom
One day we'll laugh in our joy
And we'll dance
One day we'll dance on their graves
One day we'll sing our freedom
One day we'll laugh in our joy
And we'll dance

This song is about a group of women whose husbands were imprisoned without trial and tortured by Pinochet in Chile: When their men had gone missing, they find no one to complain to so they decided to do the country's traditional courting dance with invisible partners as a gesture of grief and protest. This is an acknowledgement of the non-aggressive power of the feminine aspect. Its power is that it's ostensibly a peaceful gesture. This is dominance in passiveness, a revelation of women's inner strength and power. This responsibility actually brings the realization that one has the power to take charge of one's own life. Even if the individual adopts certain social codes or beliefs, how one act these values will prove one's unique way to be in the world. Only man has the power to transform himself and though he is basically abandoned, he has himself to rely on.

"History Will Teach Us Nothing”

If we seek solace in the prisons of the distant past

Security in human systems we're told will always always last

Emotions are the sail and blind faith is the mast

Without a breath of real freedom we're getting nowhere fast 


\title{
If God is dead and an actor plays his part \\ His words of fear will find their way to a place in your heart \\ Without the voice of reason every faith is its own curse \\ Without freedom from the past things can only get worse
}

Man has suffered abuse and oppression during past revolutions and wars and this was partially caused by man's tolerance for injustice and blind allegiance. This is a reminder for man to learn from what happened in the past. The past have seen ruthless leaders and their blind followers, and the world itself, has become witness to mass annihilation and countless crimes against humanity. Annihilating or oppressing the existence of another is a denial of the fundamental humanity of others. It is a haunting reality that there are people who continue to oppress others and the individual from his end can only avert this by asserting his right to be protected against abuse and be allowed to live in peace and harmony with others. Man is responsible for others and must take part in making the world a safer place to live in. The dignity of man is measured on his ability to exercise his rights as a human being so this entitlement must be upheld in every way possible.

\author{
"Driven to Tears" \\ Hide my face in my hands, shame wells in my throat \\ My comfortable existence is reduced to a shallow meaningless party \\ Seems that when some innocents die \\ All we can offer them is a page in some magazine \\ Too many cameras and not enough food \\ 'Cos this is what we've seen \\ Driven to tears..
}

This is an attempt to raise man's awareness of the wide range hunger that is being by experience by a large number of people in the world. He reminds man of his responsibility to help and participate in the drive to eradicate hunger in the world. People tend to run away from his responsibility to others and this has been the root of all the evil things that happen in the world. If only people will have the sense of accountability to humankind then there would be a halt in injustice and abuse.

\subsection{Absurdity}

\author{
"Lazarus Heart" \\ He looked beneath his shirt today \\ There was a wound in his flesh so deep and wide \\ From the wound a lovely flower grew \\ From somewhere deep inside \\ He turned around to face his mother \\ To show her the wound in his breast that burned like a brand \\ But the sword that cut him open \\ Was the sword in his mother's hand \\ Every day another miracle \\ Only death will tear us apart \\ To sacrifice a life for yours \\ I'd be the blood of the Lazarus heart \\ The blood of the Lazarus heart
}

Death is an uncertain occurrence and no one is ever said to be prepared for it especially the bereaved ones. Death is viewed here as regeneration, just like Lazarus rising from the dead in the New Testament. Death is seen not as an end to everything but as a renewal of strength to go on with life. The wound created by the death of a loved one will eventually heal and when it does, those who were left behind will become better and stronger individuals. A tragedy such as this is a life changing experience because this is where the individual realizes that death is a reality and one has 
to value life and strive doubly hard to live it to the fullest. This conveys the capability of man to overcome the absurdity that death brings.

$$
\begin{gathered}
\text { "Fragile" } \\
\text { If blood will flow when flesh and steel are one } \\
\text { Drying in the colour of the evening sun } \\
\text { Tomorrow's rain will wash the stains away } \\
\text { But something in our minds will always stay } \\
\text { Perhaps this final act was meant } \\
\text { To clinch a lifetime's argument } \\
\text { That nothing comes from violence and nothing ever could } \\
\text { For all those born beneath an angry star } \\
\text { Lest we forget how fragile we are } \\
\text { On and on the rain will fall } \\
\text { Like tears from a star like tears from a star } \\
\text { On and on the rain will say } \\
\text { How fragile we are how fragile we are }
\end{gathered}
$$

This song is inspired by Benjamin Linder, an engineer who was killed in 1987 by contras in Nicaragua. It reflects the unpredictability of death and how fragile the life of man is. The death of a young American in the Peace Corps in Nicaragua is an unexplainable, unacceptable event and it shows how pointless an act of violence can be. This senseless killing is an absurdity and has made people all over the world re-think how valuable and fragile a man's life is.

\title{
"Demolition Man"
}

You come to me like a moth to the flame

It's love you need but I don't play that game

'Cause you could be my greatest fan

But I'm nobody's friend, I'm a demolition man

I'm a walking nightmare, an arsenal of doom

I kill conversation as I walk into the room

I'm a three line whip, I'm the sort of thing they ban

I'm a walking disaster, I'm a demolition man

Demolition, demolition

Demolition, demolition

Every aspect of life is absurd. Man is exposed to disharmony because he is supposed to have a permanent continuous inner state of being, His life is bombarded by things that he did not anticipate nor understand because it is part of the process of being the transcendent being. In the absurd world, events happen for no reason at all, and because of its randomness, man feels as if he is tied to a chair while waiting for a bomb to tick. Man sometimes appears helpless when a tragedy happens in his life to the point that he just allows a misfortune to happen. Though it would be very difficult for him to accept and deal with it, the reality exists that it is up to the individual to choose whether he will surrender to his fate or revolt against it by facing the predicament head on.

\subsection{Dread or Anxiety}

\author{
"The Island of Souls" \\ Then what they call an industrial accident \\ Crushed those it couldn't forgive \\ They brought Billy's father back home in an ambulance \\ A brass watch, a cheque, maybe three weeks to live, \\ And what else was there for a riveter's son \\ A new ship to be built, new work to be done \\ That night, he dreamed of the ship in the world \\ It would carry his father and he
}


To a place they could never be found

To a place far away from this town,

A Newcastle ship without coals

They would sail to the island of souls.

Billy fears that his father job was too tough and dangerous for him. He feels that workers are trapped in bondage of servitude and they will die working in these ships. The dreadful day came when his father, met up with an accident at work and Billy was left devastated by his father's fate. Man chooses how he is under any circumstance and facing devastation gives him an opportunity to rise above himself and make decisions on how he will confront the dilemma he is experiencing. On one hand man is definitely thrown into the world, and on the other hand, he is radically capable of doing anything imaginable with his subjectivity. Every human being is actually responsible of how he will compose his individuality, how he is going to use his freedom to think, will, dream, project, envision, consider possibilities, invent or create.

$$
\begin{gathered}
\text { "Russians" } \\
\text { How can I save my little boy } \\
\text { From Oppenheimer's deadly toy? } \\
\text { There is no monopoly of common sense } \\
\text { On either side of the political fence } \\
\text { We share the same biology } \\
\text { Regardless of ideology } \\
\text { Believe me when I say to you } \\
\text { I hope the Russians love their children too } \\
\text { There is no historical precedent to put } \\
\text { The words in the mouth of the president } \\
\text { There's no such thing as a winnable war } \\
\text { It's a lie we don't believe anymore } \\
\text { Mister Reagan says 'We will protect you' } \\
\text { I don't subscribe to this point of view } \\
\text { Believe me when I say to you } \\
\text { I hope the Russians love their children too }
\end{gathered}
$$

This has a pro-child, anti-war theme. It is about parental fears in a nuclear age, but it ends on a hopeful note that "Russians love their children too. It is an appeal made to stop Soviets, from continuing the nonsense war if they care for their children. The character is a Russian parent fears for safety of his child and wants to save him from the ravages of nuclear war. The Cold war exemplified Russia as ruthless people but despite this, it cannot be denied that they too are humans. The Russians love their children too and would never allow a nuclear war to wipe out their race. There are no victors in wars, only victims, only lost loved ones and ruined economies. The fear of war and death one excuses no one, even the so called powerful and strong oppressors become vulnerable to the fact that they too might lose a loved one in the process.

"This War"

There's a war on our democracy A war on our dissent

There's a war inside religion

And what Jesus might have meant

There's a war on mother nature A war upon the seas

There's a war upon the forests

On the birds and the bees

There's a war on education

A war on information

A war between the sexes 
And every nation

\section{A war on our compassion \\ A war on understanding \\ A war on love and life itself \\ It's war that they're demanding}

This is a drenched treatise about how investing in war and corruption can make one rich while killing other's soul. What is happening in a war is a clash of civilizations, where the brazen disregard and lack of respect for cultures has polarized the world into two opposing camps. Nations go to war without considering the value of human life and their leaders blindly finance these, without feeling responsible for the loss of countless innocent lives. Mankind therefore, is sacrificed in exchange for power and wealth and dominance. This is a painful reality that continues to haunt the world. People suffer and die because of other people's greed for power and wealth.

"Another Day"

Every day that goes by

A new hungry baby starts to cry

Born astride a painful grave

Drowned in hunger's tidal wave

Pick a child that you can save

It'd be the only one

If Africa escapes starvation

Not only food but education

The desert grows with every minute

Trapping everybody in it

All the children look the same

They wonder why they came

But it's hard to tell the poison from the cure

It's harder still to know the reason why, why, why

The only thing I really know for sure

Is that another day, another day's gone by

This is another call to stop man's unreliability to carry his affairs. It questions why man is unable to set his priorities according to what truly benefits mankind. Men go to war and spend a fortune to secure arms to be used in war, while on the other side of the globe, hundreds of people, mostly children die of hunger due to poverty and drought. This shows how man neglects his call to be a man for others. Serving one's own interest at the expense of others is an example of a bad life. If only man would be responsible enough to think of peace instead of war then man would live the life of dignity that he deserves. The deep concern for children victims of war looms, and it is depressing for the world to accept the fact that hundreds of innocent lives are sacrificed every day.

\section{"Children's Crusade"}

Corpulent generals safe behind lines

History's lessons drowned in red wine

Poppies for young men, death's bitter trade

All of those young lives betrayed

All for a Children's Crusade

The children of England would never be slaves

They're trapped on the wire and dying in waves

The flower of England face down in the mud

And stained in the blood of a whole generation

Midnight in Soho, Nineteen Eighty-four

Fixing in doorways, opium slaves

Poppies for young men, such bitter trade 


\title{
All of those young lives betrayed
}

All for a Children's Crusade

This tackles human folly and the ravages of war. Americans look back on the First World War as a kind of glorious adventure, a mechanized breakthrough in defending the world against bullies and tyranny. But in England, it's drummed into all school children that it was an utter disaster, a grotesquely tragic waste of an entire generation of young men. Ten of thousands of these young soldiers were continually sent over the top on the Western Front to be riddled and dismembered a few feet later by a hail of machine-gun bullets. This shows how cruelly the rights of these children were violated. Their superiors condemned for their act of cowardice, for risking the lives of these children that they are supposed to protect. In the present times children are oftentimes victims of abuse. Their frailness and innocence are taken advantage of and most of them have gotten used to a life of fear.

\author{
"We Work the Black Seam" \\ This place has changed for good \\ Your economic theory said it would \\ It's hard for us to understand \\ We can't give up our jobs the way we should \\ Our blood has stained the coal \\ We tunneled deep inside the nation's soul \\ We matter more than pounds and pence \\ Your economic theory makes no sense \\ One day in a nuclear age \\ They may understand our rage \\ They build machines that they can't control \\ And bury the waste in a great big hole \\ Power was to become cheap and clean \\ Grimy faces were never seen \\ Deadly for twelve thousand years is carbon fourteen \\ We work the black seam together \\ We work the black seam together
}

Fear of the use of nuclear power is the songs theme. This was inspired by coal miners' strike, which culminated in British decimation of the British coal Industry. The miners oppose the government's plan of replacing coal with nuclear power. They are not only worried about to losing their jobs, but they also fear that using nuclear power in place of coal might endanger their lives and their families. Economic gain is not an acceptable reason for the coal miners and for them; nuclear power poses a greater threat to mankind once it becomes uncontained.

"King of Pain"

There's a little black spot

On the sun today

(That's my soul up there)

It's the same old thing as yesterday

(That's my soul up there)

There's a black hat

Caught in a high treetop

(That's my soul up there)

There's a flag pole rag

And the wind won't stop

(That's my soul up there)

I have stood here before

Inside the pouring rain

With the world turning circles

Running 'round my brain

I guess I'm always hoping 


\section{That you'll end this reign \\ But it's my destiny \\ To be the king of pain}

The character has accepted the fact that he is in pain will stay in that state indefinitely. Pain is permanent in the sense that man can never run away from it and surviving one does not assure the individual that he will survive it again the next time. This suggests a kind of negative, naturalistic view of the world, a view where things just happen and are out of anyone's control. This chaotic system creates anxiety and despair to the individual. Yet despite of his situation, the character still speaks of a soul and remains optimistic on his hope that soon his sufferings will be over.

"Driven To Tears"

Hide my face in my hands

Shame wells in my throat

My comfortable existence is reduced

To a shallow, meaningless party

Seems that when some innocents die

All we can offer them

Is a page in a some magazine

Too many cameras

And not enough food

Cause this is what we've seen

Driven to tears

Driven to tears

Driven to tears

The song talks about man's frustration over his inability to address a problem. This a reaction to seeing the less privileged go hungry while those in power or the affluent ignores the call to help these poor people. It is a song of "hopelessness" because human beings fail to bring to the needy. Protest movements and campaigns to help, proved to be ineffective. The author now is slowly losing hope that the world will soon be aware of the problem and do their part in helping those in need. More often these poor starving people are used by media as propaganda and their relationship with them ends after they've finished with using their stories for profit and popularity.

"Something the Boy Said"

In the circles we made with our fires

We talked of the pale afternoon

The clouds were like dark riders

Flying on the face of the moon

We spoke our fears to the captain

And asked what his son could know

For we would never have marched so far

To be food for a crow

Every step we took today

Our thoughts would always stray

From the wind on the moor so wild

To the words of the captain's child

Something the boy said

When I awoke this morning

The sun's eye was red as blood

The stench of burning corpses

Faces in the mud

Am I dead or am I living?

I'm too afraid to care, I'm too afraid to know

I'm too afraid to look behind me

At the feast of the crow 


\section{We spoke our fears to the captain \\ And asked what his son could know \\ For we would never have marched so far \\ To be food for a crow}

This song depicts dread as something that comes from fear of something. Fear is often time perceived as something negative but it can be helpful at times because it can make one more cautious of what to come. The group is about to embark on a perilous journey. They met a captain's son and asked if their journey would be safe and if they'd be spared from the hungry crows. The boy made a serious warning to be cautious and that he fears that they might not make it back. The journey ended with one member of the group waking up in the morning to the stench of burning corpses and he cries in horror while questioning himself if he is dead or alive. The world is full of uncertain events and one can never be prepared for it. Dealing with something that one has totally no knowledge of can trigger the feeling of fear and anxiety.

"The Wild, Wild Sea"

I saw it again this evening

Black sail in a pale yellow sky

And just as before in a moment

It was gone where the grey gulls fly.

If it happens again I shall worry

That only a strange ship could fly

And my sanity scans the horizon

In the light of the darkening sky.

That night as I walked in my slumber

I waded into the sea strand

And I swam with the moon and her lover

Until I lost sight of the land

Dread may also come from man's fear of his physical limitation or death. Fear of death is a natural fear and is present in all people. This fear is healthy, because it serves our need for self-preservation. It is present in all of us, and is the basic fear behind all fears. This reflects the anxiety one feels when faced with the death of a loved one. In this story, the man sees a ghost ship flying. In his dream he poetically swims until he finds himself on a ship. The character is lost the sea, which seems endless. Just like the surge of unanswered questions that haunts man, a search for the meaning of his father's death. Death is an experience that leaves man with lots of unanswered questions. The inability of the mind to comprehend is attributed to the intense grief that one feels upon the sudden death of a loved one. Grief weakens the mind and man will continue to feel at a loss until he totally recovers from it.

\subsection{Alienation}

“Big Lie, Small World"

I sat down and wrote this letter

Telling you that I felt better

Since you've gone and I was free

I'm so happy

I have so little time to spare now

I'm wanted almost everywhere now I make out like Casanova

Friends are always coming over

I signed my name as if I meant it

And sealed it with a kiss and sent it 


\author{
The letter had improved my mood \\ Happy in my solitude \\ But halfway home I changed my tune \\ And when I saw my lonely room \\ The mirror caught my eye \\ When I sat down, I cried \\ Big lie, small world \\ It was a big lie, small world
}

\begin{abstract}
Alienation from one-self is described as not being true to what one feels. The character, after breaking up with his girlfriend, tries to deny that he still loves her mainly because of pride. A man who just came from a broken relationship relayed to his former girlfriend through a letter that he is doing well and is not in any way affected by the break -up. He even boasted that he is living the life with other women, and that he is now free to roam around and party out with friends anytime. Later on, he finally admitted to that he feels lost without his girl. But it is quite late to retrieve the letter because the mailman has already picked it up for delivery. He desperately looked for ways to rectify the big lie he made. The song ended with the man's futile attempt to intercept the letter and totally losing his former girlfriend to another man. It came late for him to realize that need to be honest to himself. Admitting that he still loves girl will not make him any less of a man. On the contrary, being brave enough to accept one's vulnerability to love is a sure sign of a true man.
\end{abstract}

"Tomorrow we'll see"

They say the first's the hardest trick

But after that it's just a matter of logic

They have the money I have the time

Being pretty's my only crime

Ask what future do I see

I say it's really up to me

I don't need forgiving

I'm just making a living

Don't judge me

You could be me in another life

In another set of circumstances

Don't judge me

One more night

I'll just have to take my chances

For tomorrow we'll see

The song was written for a documentary on teenage transvestite prostitutes in Brazil. The transvestite prostitute in the song acknowledges the fact that society considers them as menaces. He tries to explain that he is only making a living and appeals to people not to judge him for being a prostitute. He mentions that they could be him in another life and if they were in his shoes, they wouldn't want to be discriminated and condemned. The character feels detached from the society the same way the society feels alienated from him and he wants to put a halt to this by expressing his desire to live a new life, if and when the opportunity comes. Holding on to one's true essence makes one authentic to the self, but conflict comes when the question on one's responsibility to define mankind through his actions and decisions arises.

"Fortress around Your Heart"

And if I've built this fortress around your heart

Encircled you in trenches and barbed wire

Then let me build a bridge

For I cannot fill the chasm

And let me set the battlements on fire 
This prison has now become your home

A sentence you seem prepared to pay

It took a day to build the city

We walked through its streets in the afternoon

As I returned across the lands I'd known

I recognised the fields where I'd once played

I had to stop in my tracks for fear

Of walking on the mines I'd laid

\section{And if I've built this fortress around your heart \\ Encircled you in trenches and barbed wire \\ Then let me build a bridge \\ For I cannot fill the chasm \\ And let me set the battlements on fire}

This song was inspired by Sting's divorce from his first wife. The song talks about an estranged relationship, wherein the girl totally closes his door to the boy. The boy then feels alienated as he was cut-off from the girl's world. The boy is lost and questions why the relationship has to end. Instead of succumbing to depression he tells the girl that even if she builds a fortress around her heart, he will build a bridge to fill-in the gap, He is willing to make amends and hopes that the girl will soon have a change of heart.

"I'm So Happy I Can't Stop Crying"

Seven weeks have passed now since she left me

She shows her face to ask me how I am

She says the kids are fine and that they miss me

Maybe I could come and baby-sit sometime

She says, "Are you O.K.? I was worried about you

Can you forgive me? I hope that you'll be happy."

I'm so happy that I can't stop crying

I'm so happy I'm laughing through my tears

I saw a friend of mine

He said, "I was worried about you

I heard she had another man,

I wondered how you felt about it?"

I'm so happy that I can't stop crying

I'm so happy I'm laughing though my tears

Saw my lawyer, Mr Good News

He got me joint custody and legal separation

I'm so happy that I can't stop crying

I'm laughing through my tears

I'm laughing through my tears

This is about a man who is trying to recover from his recent separation from his wife. In an attempt to hide his despair he answers “I'm so happy I can't stop crying” every time someone asks him how he is doing. He tried to think things over and struggled to understand the situation he's in. He then realized that he still has reasons to continue with his life and not being together in one roof does not mean that they cease to be a family. He chose to recover and indeed it happened. Now he utters the phrase “I'm so happy I can’t stop crying” with full conviction. Alienation is temporal if man desires it to be. No matter how grave the isolation one going through, the important thing is he has the will and ability to bounce back to reality and is able to re-live his life according to how truly wants it. 


Hundred billion bottles
Washed up on the shore
Seems I'm not alone at being alone
Hundred billion castaways
Looking for a home
I'll send an SOS to the world
I'll send an SOS to the world
I hope that someone gets my
I hope that someone gets my
I hope that someone gets my
Message in a bottle (Yeah)
Message in a bottle (Yeah)
Message in a bottle (Oh)
Message in a bottle (Yeah

The theme of the song is man's isolation from the world. It is about a castaway who sent his call for help through a message in a bottle. The song expresses the sentiments of a lonesome person as he feels left alone in this world. He desperately seeks help to get rid of this alienation and later on realized that there are many people like him who feel that they are abandoned and neglected. This fact only means that he was never alone in his loneliness, that like him there are also others who faces the same dilemma. People in the middle of a crisis or depression should never give up hope and must have the attitude that he can and will rise above all predicaments.

\section{"Send Your Love"}

There's no religion but the endless ocean

There's no religion but the moon and stars

There's no religion but time and motion

There's no religion, just tribal scars

Throw a pebble in and watch the ocean

See the ripples vanish in the distance

It's just the same with all the emotions

It's just the same in every instance

There's no religion but the joys of rhythm

There's no religion but the rites of Spring

There's no religion in the path of hate

No prayer but the one I sing

Send your love into the future

Send your precious love into some distant time

And fix that wounded planet with the love of your healing

Send your love

Send your love

There's no religion but sex and music

There's no religion that's right or winning

There's no religion in the path of hatred

Ain't no prayer but the one I'm singing

Send your love

Send your love

Part of being free is man's right to choose what he wants to believe in. He is given free will and knowledge so he can decide on the question of whether he believes in the existence of God or not. One might have experienced alienation from faith at one point of his life and this phase is a welcomed one because being subjective beings, analyzing and feeling the lack of faith is a prelude to having it at the end of the whole process. This song is about attaining human salvation and how it 
can be attained through love alone. It says "There is no religion but sound and dancing”, which actually means that religion has become insignificant in this modern time. This means that religion does not determine the actuality of a person. That even without religious affiliation man can still live a fulfilled life through his deeds and actions. He may belong to a particular group or may not even recognize the existence of God, but what is important is how he is as a man for himself and others. Religion here does not portray a major role in the individual's quest for the authentic life.

"All this Time"

I looked out across

The river today

I saw a city in the fog and an old church tower

Where the seagulls play

I saw the sad shire horses walking home

In the sodium light

I saw two priests on the ferry

October geese on a cold winter's night

And all this time, the river flowed

Endlessly to the sea

Two priests came round our house tonight

One young, one old, to offer prayers for the dying

To serve the final rite

One to learn, one to teach

Which way the cold wind blows

Fussing and flapping in priestly black

Like a murder of crows

And all this time, the river flowed

Endlessly to the sea

If I had my way I'd take a boat from the river

And I'd bury the old man

I'd bury him at sea

The main character in the song is a man who wishes to bury his father at sea as an individualized last show of respect. Instead he suffers through learned and learning priests who subjected the expired one to their canonized rituals. All of those rites however, have their foundation in the existence of an invisible savior who seems to have little effect on the real world. From that context, it appears now that no faith in any god has ever prevented an individual or worshipping culture the right to respectful demise. The man who initially seeks the priests to give his departed loved one the final rites had really doubts in his faith and in the officiating priests as well. In his own mind he prefers that he bury the old man at the sea, instead of going to the ritual. It is his realization that these rituals are not necessary for man to reach eternal life and salvation. The song shows a loss of faith on men in congregations and the character manifested it on his desire to follow the old tradition of burying the dead at the sea, instead of letting it go through the religious practice of giving final rites to the dead.

"Rock Steady"

It rained for forty days and forty long nights

I'd never seen rain like it and it looked like our old friend Was being proved right

We had no time to worry though there was just to much to do

Between the signified monkey and the kangaroo

We had to wash all the animals we had to feed them too

We were merely human slaves in a big floating zoo

She said, "Hey Baby I don't mean to be flip

But it seems this old man is on some power trip" 
I said, "No, no sugar you must be wrong

I mean look at the size of this boat we're on.

We're as safe as houses, as safe as mother's milk

He's as cool as November and as smooth as China silk

He's God's best friend, he's got a seat on the board

And life may be tough but we're sailing with the Lord."

Rock steady Rock steady

Rock steady Rock steady

Rock steady Rock steady

Rock steady Rock steady

The song shows greedy men who use religion and faith for personal gain. Religion is a powerful force in society and sometimes the faith of others in God is exploited by people in order to gain profit. The characters in the story were fooled into being slaves of a man who claims to know the way to save mankind and other living things from a big flood that threatens to destroy the world. In real life, there are evangelists who are clever manipulators; they exploit people's fears and abuse their best intentions for money and power. Part of the unspoken belief is that the world will end in a violent configuration and somehow righteous will survive through the power of God. But in reality, a holocaust will spare no one and the question on whose soul will be saved can only be answered by the kind of life that one has lived.

\title{
8.5 Authenticity
}

\author{
"Englishman in New York" \\ Modesty, propriety can lead to notoriety \\ You could end up as the only one \\ Gentleness, sobriety are rare in this society \\ At night a candle's brighter than the sun \\ Takes more than combat gear to make a man \\ Takes more than a license for a gun \\ Confront your enemies, avoid them when you can \\ A gentleman will walk but never run \\ If "Manners maketh man" as someone said \\ Then he's the hero of the day \\ It takes a man to suffer ignorance and smile \\ Be yourself no matter what they say \\ Be yourself no matter what they say \\ Be yourself no matter what they say \\ Be yourself no matter what they say \\ Be yourself no matter what they say... \\ I'm an alien, I'm a legal alien \\ I'm an Englishman in New York \\ I'm an alien, I'm a legal alien \\ I'm an Englishman in New York \\ I'm an alien, I'm a legal alien \\ I'm an Englishman in New York \\ I'm an alien, I'm a legal alien \\ I'm an Englishman in New York
}

This song expresses the grasping of oneself amidst discrimination and the ability to remain a being with others despite being violated is expressed in the song. This is a tribute of Sting to one of the gay community's most celebrated elder statesmen, Quentin Crisp. He was a homosexual in 
England at a time when being so was physically dangerous and he was with no apologies, in such a flamboyant and brave way that he was an example to everyone. He lived his life in an individual way in a society that is vicious and malevolent, making him more courageous than muscle men toting arms and guns. True courage is having the ability to live one's self in its truest, most authentic sense. He is an Englishman in New York who chooses to do what he prefers and is proud of his sexuality. He denounces violence and declares that being reserved and polite makes the individual prone to abuse of people. He seeks for soberness in the world which he finds lacking. The character prefers to keep silent rather than confront his enemies. This is a manifestation of what authentic living is; the individual's willingness to stand up for his true self despite pressure from society and taking it a step further by taking responsibility not only for himself but also for others.

"The Shape of My Heart"

And if I told you that I loved you

You'd maybe think there's something wrong

I'm not a man of too many faces

The mask I wear is one

But those who speak know nothing

And find out to their cost

Like those who curse their luck in too many places

And those who fear are lost

I know that the spades are the swords of a soldier

I know that the clubs are weapons of war

I know that diamonds mean money for this art

But that's not the shape of my heart

This song takes the subject of man embracing his true self. The song is about a master card-player who plays to find some divine, almost spiritual meaning to the probabilities of the game. He is too engrossed with playing it that he becomes emotionless and this adversely affects his relationship with others. Despite of feeling indifferent he decides to remain the man that he is. He plays cards not for monetary gain and he is not there to make friends as shown in the line that "he is only a man of one 'face'which is the mask'he hides behind. He does not exist to please anyone but himself and unlike others he never loses a game because the purpose of him playing it is purely for spiritual motives only. Man must strive to have an authentic existence. Though life has been presented to him as uncertain, unreasonable and sometimes cruel, he needs to experience all of these conflicts in order for him to transcend and go beyond what he is at the moment. He will make use of his subjectivity as he experience the existential characteristics that comes with life and this long hard climb towards the authentic life is the very thing that will make man whole and true in the end.

\author{
“Epilogue Nothing 'Bout Me” \\ Lay my head on the surgeon's table \\ Take my fingerprints if you are able \\ Pick my brains, pick my pockets \\ Steal my eyeballs and come back for the sockets \\ Run every kind of test from A to $Z$ \\ And you'll still know nothing 'bout me \\ Run my name through your computer \\ Mention me in passing to your college tutor \\ Check my records, check my facts \\ Check if I paid my income tax \\ Pore over everything in my C.V
}

The character here insists that no matter how other people define an individual, it can never be done. Man can never be labeled; he can never be defined by others. The character struggles with people who try to define him according to how they see him. He insists that even if people assume 
that they already know him, there are still things left unseen that only he can give meaning and logic to. The song says that behind the simplicity of man lies a depth of complexities. History cannot characterize a person. It may tell a few things about the individual or may reinforce a person through the lessons derived from it. But it can never impose an identity to the individual. Even the past cannot pre-determine the individual and his nature of being transcendent makes him more complex. Whenever people internalize the objectified identity granted to them by other people or by society, it is tantamount to self-deception.

\section{“Dead Man's Rope”}

Walk away in emptiness, walk away in sorrow, Walk away from yesterday, walk away tomorrow, Walk away in anger, walk away in pain Walk away from life itself, walk into the rain

All this wandering has led me to this place Inside the well of my memory, sweet rain of forgiveness I'm just hanging here in space

The shadows fall Around my bed When the hand of an angel, The hand of an angel is reaching down above my head

All this wandering has led me to this place Inside the well of my memory, sweet rain of forgiveness Now I'm walking in his grace I'm walking in his footsteps Walking in his footsteps, Walking in his footsteps

All the days of my life I will walk with you All the days of my life I will talk with you All the days of my life I will share with you All the days of my life I will bear with you

Walk away from emptiness, walk away from sorrow, Walk away from yesterday, walk away tomorrow, Walk away from anger, walk away from pain Walk away from anguish, walk into the rain.

Man can also achieve an authentic life by taking "blind leap of faith". or a"leap in the arms of God". Authenticity happens when a person lives in the moment and is ready for any outcome with no excuses. After living his life according to the way he desires he must be prepared to have a "leap of faith" which means having a blind, personal commitment to God at every moment of one's life. The fact that this leap is completely independent of reason is what makes it so strong. It is not an abrupt process because it is based purely on one's faith and it cannot be immediately achieved through affiliation with any group. It is a lived experience, a journey whose end can only be decided by the individual. This is a song about a dying man's wish to go back to his Creator. He has lived am inauthentic life and seeks renewal of his faith during the last days of his life.

"This Cowboy Song"

I've been the lowest of the low on the planet

I've been a sinner all my days

When I was living with my hand on the trigger

I had no sense to change my ways

The preacher asked if I'd embrace the resurrection

To suck the poison from my life

Just like an existential cowboy villain 
His words were balanced on my knife

Devil to pay, on judgement day

Would Jesus strike me down if I should pray?

This cowboy song is all I know

To bring me back into your arms

Your distant sun, your shining light

You'll be my dog-star shining tonight

\author{
Every night \\ Every night \\ All my distances afar
}

\begin{abstract}
This cowboy song, is all I know
To bring me back into your arms

This cowboy song, this cowboy life

I'll be your dog-star shining tonight
\end{abstract}

The song is about of a cowboy who wants to repent his ways, and tries to express it in prayers. Unfortunately he hasn't got the words with which to pray, so he made use of what he has and that is his cowboy song. The cowboy lived an unguided life and because of this, he never had the chance to live a life of faith. He now tries to live a new life by turning away from what he believes is evil and walking into God's path despite his doubts and fears that he might not good enough to lead this journey back to the Creator.

\title{
9. Characteristic of Existentialism that is Most Frequently Used and Reflected in the Lyrics of the Songs by Sting
}

Table 1. Characteristic of Existentialism that is used and Reflected in the Lyrics of the Songs by

\begin{tabular}{|l|c|c|c|}
\hline \multicolumn{1}{|c|}{ Characteristics } & $\begin{array}{c}\text { Total no. of } \\
\text { songs } \\
\text { analyzed }\end{array}$ & $\begin{array}{c}\text { No. of times } \\
\text { reflected in } \\
\text { the lyrics }\end{array}$ & Percentage \\
\hline $\begin{array}{l}\text { Free will or freedom of choice and } \\
\text { responsibility of actions }\end{array}$ & 30 & 6 & $20 \%$ \\
\hline Absurdity & 30 & 3 & $10 \%$ \\
\hline Dread or Anxiety & 30 & 10 & $33 \%$ \\
\hline Alienation & 30 & 8 & $26 \%$ \\
\hline Authenticity & 30 & 5 & $16 \%$ \\
\hline
\end{tabular}

Based on the table 1, among the five Existential characteristics, the most frequently used and reflected in the lyrics of the songs by Sting is Dread or Anxiety. Out of the 30 songs analyzed, 10 songs or 33\% reflects Dread or Anxiety in their lyrics. Alienation comes in next with 8 songs out of 30 or $26 \%$, followed by Free will/freedom of choice and responsibility of actions with 6 out of 30 songs or $20 \%$, Authenticity with 5out of 30 or $16 \%$ and Absurdity with 3 out of 30 songs or $10 \%$.

Sting communicates his concept and spreads his critique implicitly via his songs that include nihilism. Sting's essential role is examined and quickly described. By connecting those two words and also Sting's past religion, one occurrence from that period is revealed as the force that inspired Sting to write the song. As a musician, this is how Sting expresses and criticizes his ideas. Mercury had an idea to utilize the songs as the title in the start of the lyric's creation, but Sting's songs appeared to be the one in the end. Finally, Sting's ideological interest is explored via the lens of existentialism. Sting implicitly criticizes religious authorities as well as certain people who abuse 
the nature of God, religion teaching, and their position as the implementers and watchmen of God's commandments in order to get what they want, such as power and authority.

\section{Conclusions}

Based on the thorough analysis of the use of existentialism in the lyrics of the songs by Sting, this research makes the following conclusions. The existential characteristics used in the lyrics of the songs by Stings are Freedom and Responsibility, Absurdity, Dread, Alienation and Authenticity; These Existential characteristics were reflected in the lyrics of (30) thirty songs of Sting; Among the five characteristics of Existentialism mentioned, Dread or Anxiety is the most frequently used and reflected in the lyrics of the songs by Sting.

Nonetheless, they contribute to future study on the effectiveness of Sting's song lyrics in restoring, maintaining, and promoting psychological and physical health. Of course, in our study, we focused on the larger sense of meaning that gives an overall feeling of existential fortitude. The idea that nostalgia has consequences for various levels of meaning-making, even extending to a basic understanding of relationships between experiences and events, is still being researched.

\section{Competing Interest Statement}

The author has read and approved the manuscript and take full responsibility for its contents. No potential conflict of interest was reported by the author(s).

\section{Acknowledgements}

I wish to convey my thanks to the reviewers and editors of this manuscript for publishing our manuscript in this scholarly journal.

\section{References}

[1] Cage, John. 2011. Silence: Lectures and Writings, 2nd edition. Middletown: Wesleyan University

[2] Flynn, Thomas R. (2012). Existentialism. The Journal of Speculative Philosophy, 26(2), 247-267. doi: 10.5325/jspecphil.26.2.0247

[3] Gable, Christopher. Words and Music of Sting. Online Journal. ISBN 0-7434-5081-7, 2009.

[4] Gosetti-Ferencei, Jennifer. (2021). Existentialism as Literature: The Twentieth Century the Twentieth Century.

10.1093/oso/9780190913656.003.0006.

[5] Malpas, Jeff. (2012). Existentialism as literature. 10.1017/CCOL9780521513340.015.

[6] Mooney, E. (2018). Kierkegaard's Disruptions of Literature and Philosophy: Freedom, Anxiety, and Existential Contributions. In Ziolkowski E. (Ed.), Kierkegaard, Literature, and the Arts (pp. 55-70). EVANSTON, ILLINOIS: Northwestern University Press. doi:10.2307/j.ctv3znxrg.8

[7] Pacifici, S. (1955). Existentialism and Italian Literature. Yale French Studies, (16), 79-88. doi:10.2307/2929150

[8] Rochberg, George. 1988. Aesthetics of Survival: A Composer's View of Twentieth-Century Music. Edited by William Bolcom. Ann Arbor: University of Michigan

[9] Sartre, Jean-Paul. 1987. Existentialism and Human Emotion. Tranlated by Bernard Frechtman and Hazel E. Barnes. New York: Kinsington

[10] Skottun, Gro \& Krüger, Åshild. (2021). Phenomenology and existentialism. 10.4324/9781003153856-4.

[11] Slamova, Karolina. (2019). EXISTENTIALISM IN LITERATURE. 10.5593/SWS.ISCAH.2019.1/S27.061.

[12] Waters, B. (1950). Existentialism in Contemporary Literature. Prairie Schooner, 24(1), 87-94. Retrieved from http://www.jstor.org/stable/40624203 